Historic, Archive Document

Do not assume content reflects current scientific knowledge, policies, or practices. 



\section{Chimney Spring Forest}

Fire History

John H. Dieterich

$\ln$

$$
\begin{aligned}
& 1912 \\
& \begin{array}{l}
164 \\
405 \\
10
\end{array} \\
& 100 . \\
& 17450 \\
& 789 . \\
& 1721 . \\
& 1708 .
\end{aligned}
$$

$$
w^{3}
$$

\section{7.} 1676 . 1660

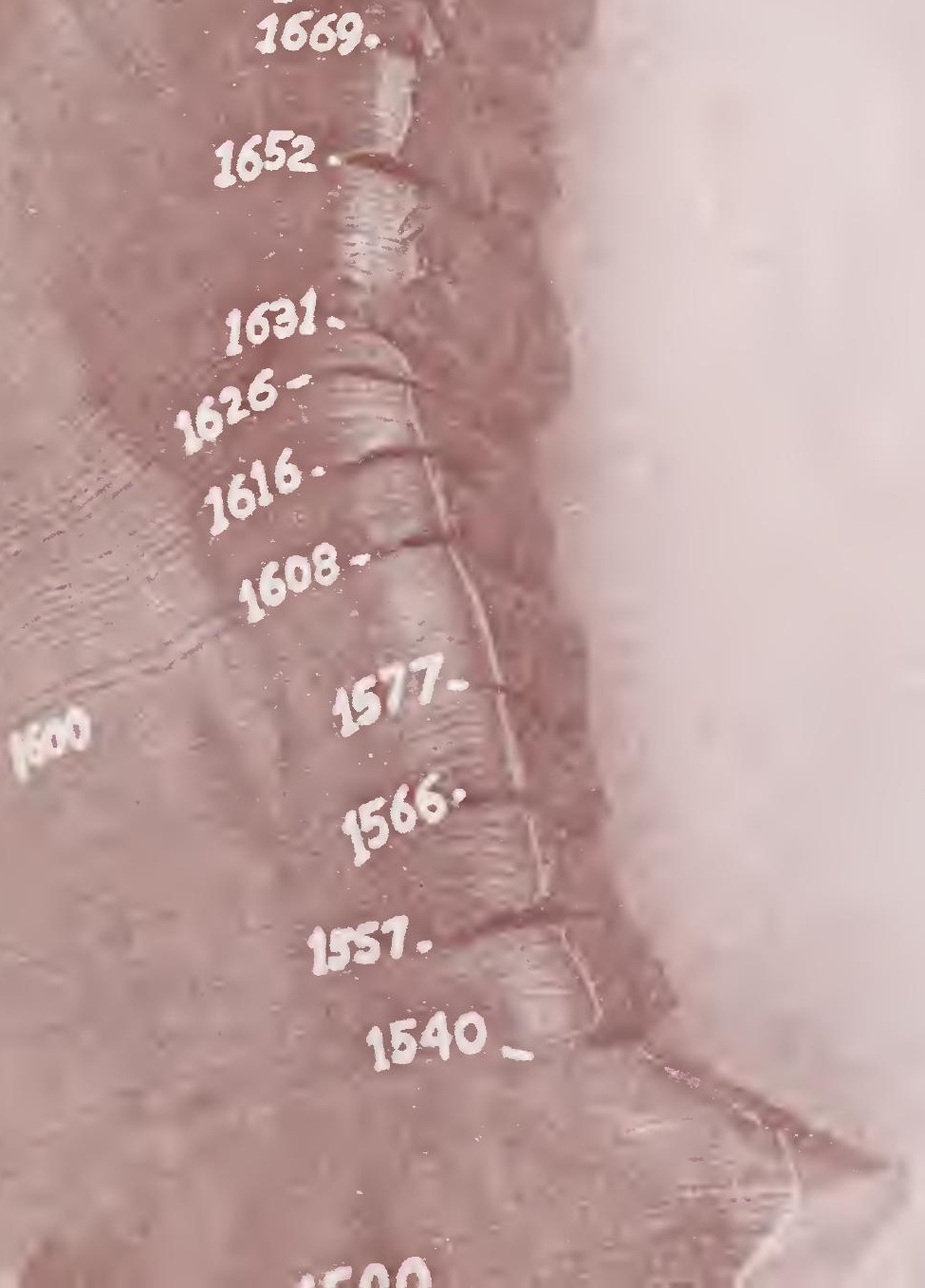

Research Paper RM-220 Rocky Mountain Forest and Range Experiment Station Forest Service U.S. Department of Agriculture 


\title{
Chimney Spring Forest Fire History
}

\author{
John H. Dieterich, Research Forester \\ Rocky Mountain Forest and Range Experiment Station'
}

\begin{abstract}
Analysis of data from seven specimens revealed a composite fire interval in ponderosa pine of 2.4 years from 1745 to 1876 (122 years), a shorter interval than previously reported. In all cases, composite fire intervals were shorter than individual specimen intervals.
\end{abstract}




\title{
Chimney Spring Forest Fire History
}

\author{
John H. Dieterich
}

\author{
Management Implications
}

Information on historical fire frequencies in the Chimney Spring area indicates that fires were common in the ponderosa pine forests of northern Arizona prior to 1876 . For the period studied, individual tree average fire intervals ranged from 4.4 to 17 years. The composite fire interval (CFI) for the entire 336-year period, 1540-1876, represented by one or more specimens averaged 4.9 years. If the CFI is computed for the 122-year period (1754-1876) when two or more specimens were used, the average interval was 2.4 years. For various other selected time-spans, even shorter CFI's were identified. This knowledge provides a sound basis for continuing the prescribed burning interval research started near Chimney Spring in 1975. Results of this study will provide the land manager with additional knowledge needed to use fire safely and effectively in the protection and management of natural resources.

The Chimney Spring fire history study demonstrates the importance of developing a CFI in ponderosa pine to determine more precisely the frequency of past fires for a particular location. Two factors can improve on the accuracy and utility of the CFI: (1) using as many fire-scarred specimens as possible from a small area, and (2) utilizing full stump cross sections rather than portions of sections so that the maximum possible number of fire scars can be included in the analysis.

A CFI, such as the one developed for the Chimney Spring area, is not a prerequisite for intelligent application of landmanagement practices. However, information on historical fire frequency and modern fire occurrence patterns can reinforce the manager's appreciation of the fact that wildfires of today bear little resemblance to those occurring during centuries past, and that intelligent use of prescribed fire will not destroy the timber stand that the manager is trying to protect.

\section{Introduction}

Recognition of the importance of fire as a natural agent of change in various ecosystems has brought about a corresponding interest in frequency, character, and impact of historical fires. A more complete knowledge of historical fires can aid in understanding the role of fire as a process in the development of valid ecosystem theories. This understanding will, in turn, permit effective implementation of prescribed natural fire programs, realistic planning in implementing new fire management policies, and preservation of valuable historical fire data having a considerable amount of public appeal and interest.

Knowledge of local fire history provides a better understanding of existing stand structure and helps in the interpretation of changes in age-class distribution, fuel accumulation, understory plant communities, natural regeneration, and nutrient cycling. When used for specific sites, fire history data can be used to help provide a scientific basis for using prescribed fire at various intervals. Data from the current study will be applied to the Chimney Spring Prescribed Burning Interval Study, ${ }^{2}$ established in

${ }^{2}$ Study Plan 75.1.5 on file. Fuels Management Research Project, Forestry Sciences Laboratory, Tempe, Ariz. Sackett, Stephen S., and John H. Dieterich. 1976. Prescribed burning interval study for continued hazard reduction in all-age ponderosa pine stands.
1975 on a 90-acre (36-ha) tract of virgin ponderosa pine on the Fort Valley Experimental Forest near Flagstaff, Ariz. Site-specific fire history data for the Chimney Spring study area were unavailable. However, an earlier analysis of three fire-scarred stump cross sections taken from widely scattered locations on the Coconino National Forest yielded average fire intervals of 7,12 , and 12 years. ${ }^{3}$

This paper describes the frequency of fire on a relatively small area of ponderosa pine (Pinus ponderosa Laws.) on the Coconino National Forest in northern Arizona, suggests possible reasons for fire occurrence, and speculates on the characteristics of the ecosystem that existed around the turn of the century.

\section{Literature Review}

In early reports, Plummer (1912), Munger (1917), Boyce (1921), and Craighead (1927) discussed various aspects of fire history, fire ecology, climatic response, and fire damage as reflected in tree rings. Show and Kotok (1924) described fire frequency in the California pine region, concluding that fire had been an important ecological factor for centuries and that the fire interval averaged about 8 years for all areas

${ }^{3}$ Unpublished data. Fuels Management Research Project, Forestry Sciences Laboratory, Tempe, Ariz. 
studied. Their work also included observations on the formation of fire scars and the susceptibility of various tree species to fire scarring. Kotok (1933) described a study of fire incidence and damage in the mixed conifer type (of which ponderosa pine was a component) on the Stanislaus National Forest. On the basis of tree ring records, he identified 221 distinct fires that moved through the 74-acre study area between the years 1454 and 1912, leaving scars on $18 \%$ of the trees. Details of species composition of sampled trees and methods of cross-dating and verification were not included.

Lemon (1937) found a fire interval of 31 years on a single, old-growth ponderosa pine in the Black Hills of South Dakota. Keen $(1937,1940)$ studied ponderosa pine longevity and climatic cycles in eastern Oregon as evidenced by tree-ring records and identified average fire intervals for individual trees of 16 to 18 years.

Weaver (1943) recognized fire as an important ecological and silvicultural factor in the ponderosa pine region of the Pacific Slope and recommended intensive research that would permit more effective use of prescribed fire as a silvicultural tool and in the protection and management of the ponderosa pine type. In 1951, Weaver described fire history on the Whiteriver and San Carlos Apache Indian Reservations using cross sections from four widely scattered fire-scarred stumps. Average fire intervals ranged from 4.8 to 6.9 years. He described a fire-scarred ponderosa pine collected from the Kaibab National Forest north of Grand Canyon National Park that had 19 fire scars from a 226-year period for an average interval of 11.9 years.

Subsequently, Weaver $(1955,1959,1961)$ sampled firescarred stump cross sections from ponderosa pine found on Colville, Warm Springs, and Yakima Indian Reservations and identified average fire intervals ranging from 8 years (Colville) to 47 years (Warm Springs). However, most of the intervals averaged between 4.8 and 11 years. Weaver (1974) summarized most of this work in a chapter entitled "Effects of Fire on Temperate Forests: Western United States." He concluded that historical fires have burned "as frequently as fuel accumulated in sufficient quantity to support combustion over the forest floor, whenever weather conditions were favorable and whenever lightning strikes or Indians cause them to start."

Soeriaatmadja (1966) expanded on the work done by Weaver on the Warm Springs Indian Reservation. He inspected freshly cut ponderosa pine stumps of fire-scarred trees from four areas that were being logged and identified average fire intervals from 14.2 to 30.2 years. The longer intervals were on the higher, more mesic sites. He recognized that the actual years of individual fires might be off by a slight amount because his work did not incorporate cross-dating and verification of exact fire years using master tree-ring chronologies. For example, he checked fire scars on an area that was known to have burned in 1938 . He found 10 stumps that agreed with the 1938 date, 17 stumps that showed evidence of the fire occurring in 1939, and 8 stumps that were dated 1940. No fires had burned on the area in 1939 and 1940, indicating that, in the ponderosa pine type, reliable dating is difficult without cross-dating.
Recent studies by Arno (1976), Rowdabaugh (1978), McBride and Laven (1976), and Hall (1976) summarize fire frequency for ponderosa pine stands in four other regions of the western United States. Arno identified fire intervals of 6 , 10, and 11 years on the Bitterroot National Forest in western Montana and found that fire history and forest habitat type were closely interrelated. He determined that, for all habitat types that include ponderosa pine as one of the stand components, fire frequency for the stand reflected a higher fire incidence than for any one of the individual fire-scarred trees used to determine fire frequency for the stand. (Results of the study reported on in this paper show this same relationship existing between individual tree fire histories and the composite history for the Chimney Spring area.)

Rowdabaugh (1978) reported on fire frequency in the ponderosa pine-mixed conifer forest of the Colorado Front Range. A mean fire frequency for the study area was computed to be 84 years; but for various smaller units within the larger study area, the intervals ranged from 28 to 165 years. The intervals reported in Rowdabaugh's study are longer than for ponderosa pine stands in other parts of the West. No explanation is given for this apparent anomaly.

McBride and Laven (1976) analyzed fire scars on 26 ponderosa pines collected over a wide area in the San Bernardino Mountains in southern California. They identified a fire interval of 10 years prior to 1905 , when organized fire protection began, and an interval of 22 years thereafter.

Hall (1976), reporting on management implications of fire effects in the Blue Mountains of Oregon, described an average fire interval of 10 years and suggests that this 10 . year average interval could be used as a guide for determining how frequently the area should be treated with prescribed fire.

\section{Data Collection and Analysis}

Three kinds of fire-scarred material were used to reconstruct the fire history for the Chimney Spring area: stump cross sections from freshly cut, fire-scarred trees removed in a logging operation on the adjacent area; an old stump showing well preserved fire scars; and a "half section," or wedge, from a living tree. Figure 1 shows the location of the sample trees in relation to the prescribed burning plots. The seven sample trees selected for analysis are within an area having a radius of approximately 1,200 feet $(365 \mathrm{~m})$. Six of the seven specimens are within an area having a radius of 660 feet $(201 \mathrm{~m})$.

Fire-scarred material was processed at the Laboratory of Tree-Ring Research, University of Arizona, Tucson. Cross sections were surfaced, fire scars were identified, and crossdating and verification were completed using an established chronology for the area. In order to reconstruct a composite fire history for the stand, it was imperative that exact dates for each cross section be determined so that the composite would accurately reflect the years in which fires occurred. 
An alternative to this method is a technique developed by Arno and Sneck (1977) in which a master chronology was developed that involved the adjustment of fire-scar dates by as much as 3 years. Adjustments were made based on the fact that some dates are accurate and others are approximate or otherwise difficult to interpret.

In reconstructing a composite historical fire interval for the Chimney Spring area, some basic assumptions have been made:

1. That a fire starting within the general area where the samples were taken would have had a good chance of spreading over the entire area.

2. That a fire spreading into the area from the outside also probably would have spread over the entire area.

3. That these fires would not necessarily have burned every square foot of surface area because of fuel discontinuity, thus leaving some trees unscarred with each passing fire.

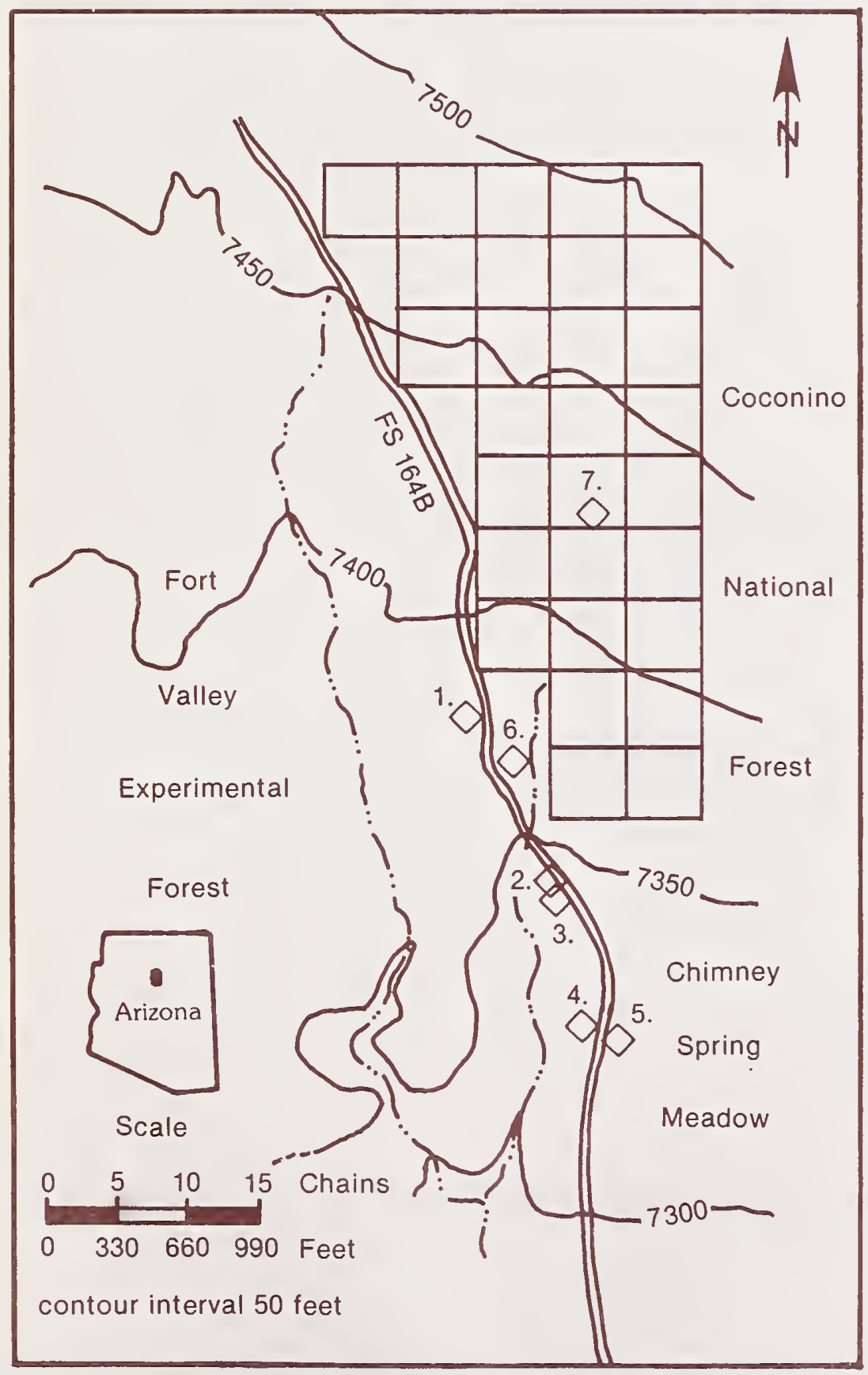

Figure 1.-Fire history sample tree locations. Chimney Spring prescribed burning study site 3.5 miles northwest of Flagstaff. Individual plots are $2 \frac{1}{2}$ acres ( $1 \mathrm{ha}$ ) in size.

\section{Results}

Figure 2 displays the results of individual tree analyses and provides information on tree age, number and dates of fire scars, average fire intervals, date of most recent fire, and whether one or two sides of the fire scar were included in the dating process. Across the bottom of the figure is a composite of fire-years made up from dates as reflected by each individual specimen. This display makes it possible to develop a CFI for the entire period represented by the treering cross sections, or for any portion of that period. Figure 2 reveals a number of facts and interesting relationships:

1. The last fire in the area was in 1876 , as shown by five of seven specimens.

2. Tree 7 (536 years old) contained 31 identifiable fire scars, with the initial scar having formed in 1540 (fig. 3).

3. Complete cross sections (trees 3 and 6 ) revealed that fires do not always scar both sides of a "catface." Therefore, when only one side of the scarred area is used for determining fire interval, the count will be conservative.

4. Specimen 6 was a small dead stump heavily impregnated with pitch. It was impossible to determine the exact year in which the tree had been cut because the sapwood had deteriorated leaving only the pitch-impregnated heartwood and fire scars. Using a master tree-ring chronology for the area, the outside ring was dated at 1873 . This tree averaged one fire every 4.4 years throughout the 88-year period, 1785-1873. Included in the total fire sequence is a 14year period (1836-1850) where six fires scarred the tree at intervals of $3,2,2,2,3$, and 2 years.

5. A gap appears in the composite fire history during the 8-year period, 1794-1802. The fire-free gap ranged from 11 years on specimen 6 to 20 years on specimen 2. This gap should not necessarily be interpreted to mean that there were no fires in the area during this period; rather, that none of the seven specimens were scarred by fires during this time span.

6. The average age of the trees when the first fire scar occurred was 121 years with a range of 63-192 years.

7. There were no instances where any of the seven specimens revealed scars in successive years. Intervals of two years were revealed on only two specimens (6 and 7).

8. There were no years when fire scars were detected on all seven specimens. The last fire recorded on the area (1876) was recorded on five of the specimens and a fire in 1785 was reflected on four of the seven specimens.

Table 1 summarizes CFI's for several different periods. Period 1 encompasses fire-scar data for all seven specimens, although fire frequency for two-thirds of this period is represented by only one specimen (7).

Period 2 provides the longest span of time (122 years) that includes data from all seven specimens. The resulting interval (2.4 years) represents a ponderosa pine fire frequency far shorter than any previously reported in the literature. 


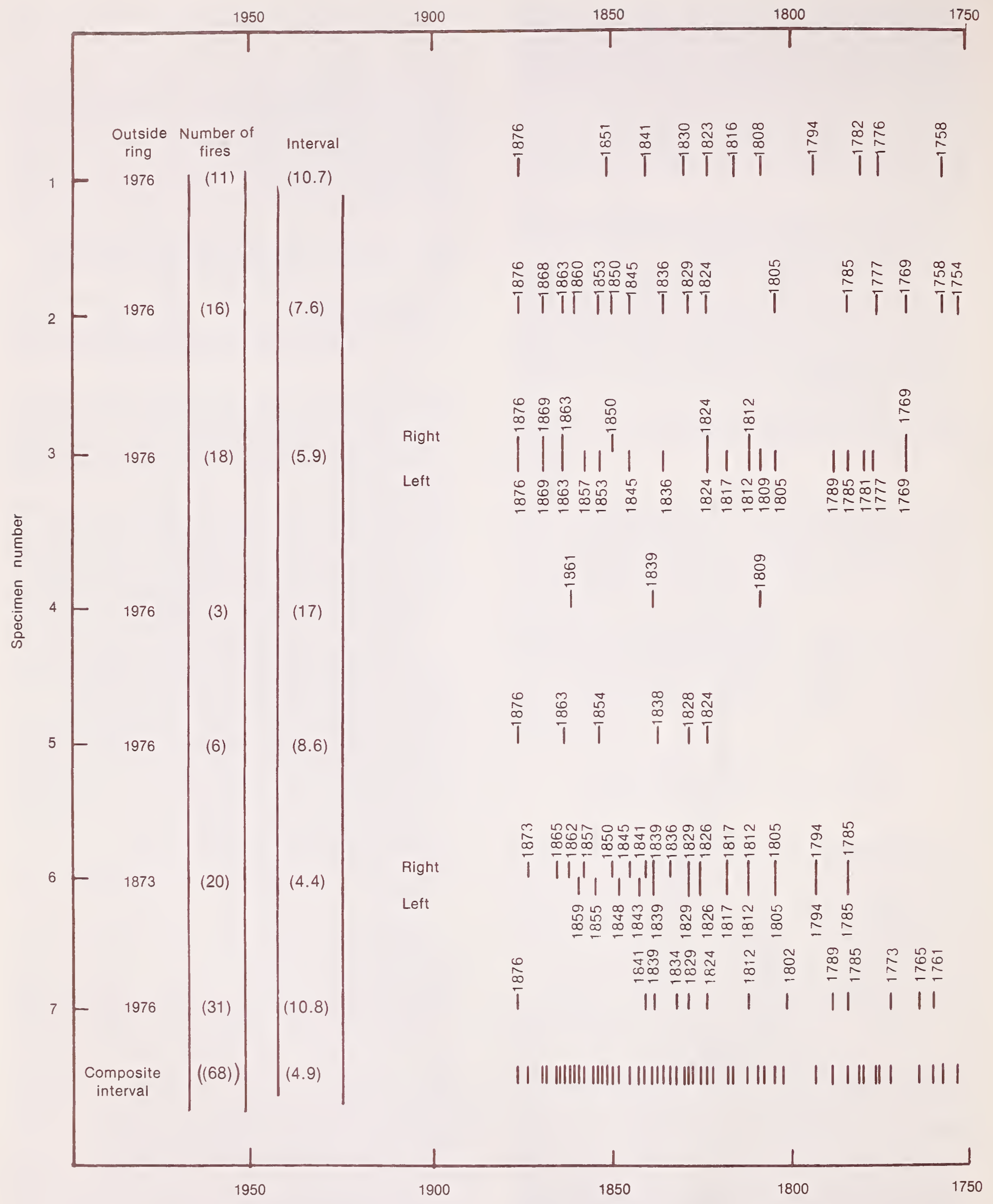

Figure 2.-Chimney Spring composite fire interval. 


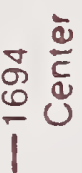

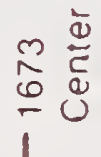

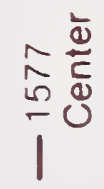

No Center

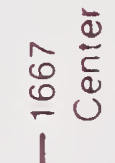

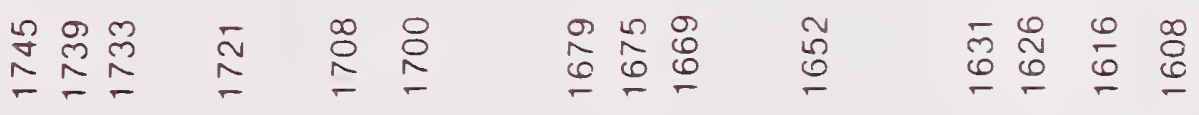

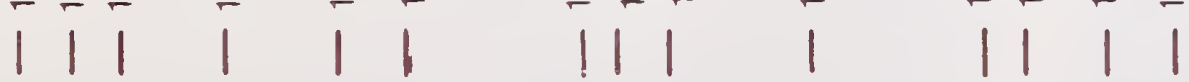

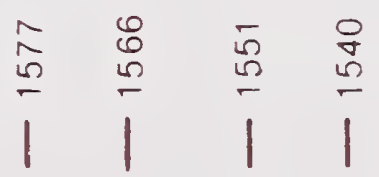

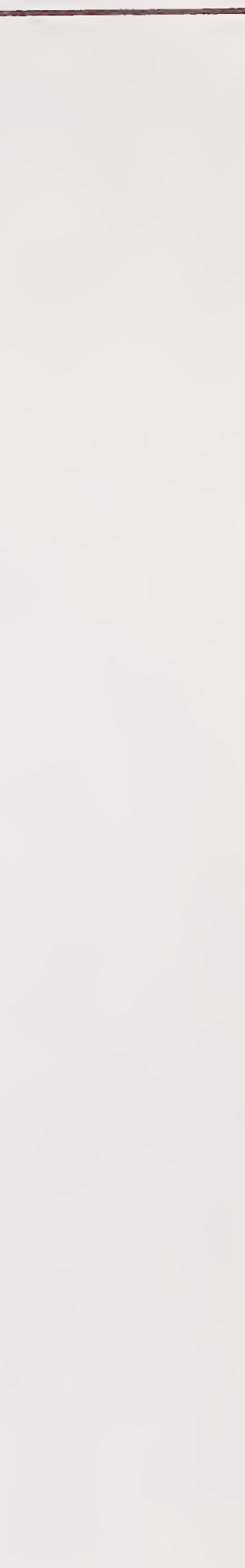

No Center

2

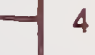

$111|1| 1 \mid 111 \quad 1 \quad 1111101111$ 


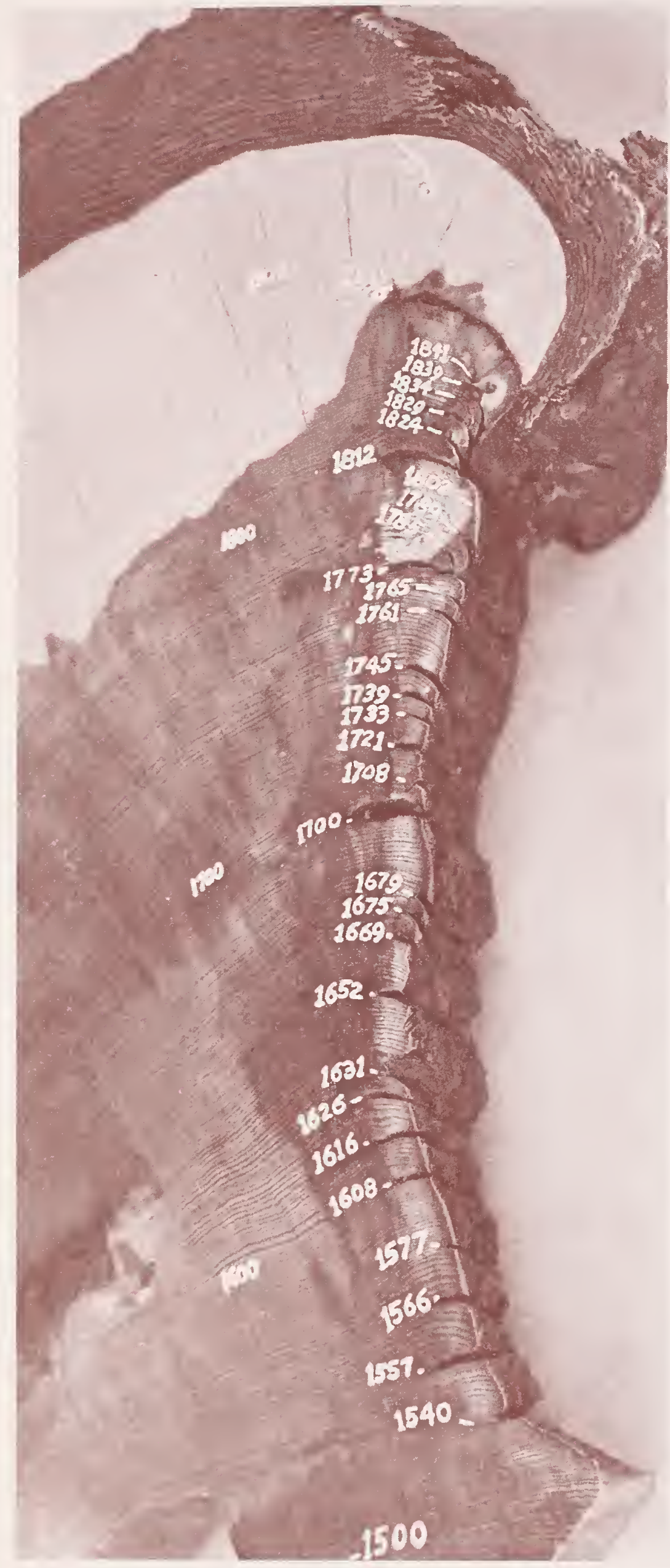

Figure 3.-Fire scarred cross section from specimen 7 , Chimney Spring plots. Thirty-one scars are identifiable between the years 1540 (first scar) and 1876 (last scar). This tree appeared to grow at a normal rate for about the firs 150 years then slowed to a sustained rate of about 80 rings per inch. The section measures 11 inches $(28 \mathrm{~cm})$ from the outer ring (1976) to the inner ring (1440).
Table 1.-Composite fire intervals, Chimney Spring

\begin{tabular}{ccccc}
\hline Period & Time span ${ }^{1}$ & $\begin{array}{c}\text { Number } \\
\text { of years }\end{array}$ & $\begin{array}{c}\text { Number of } \\
\text { recorded } \\
\text { fires }\end{array}$ & Interval \\
\hline & & & & years \\
1 & $1540-1876$ & 336 & 68 & 4.9 \\
2 & $1754-1876$ & 122 & 50 & 2.4 \\
3 & $1800-1876$ & 76 & 37 & 2.1 \\
4 & $1820-1876$ & 56 & 30 & 1.9 \\
5 & $1824-1869$ & 45 & 26 & 1.7 \\
6 & $1850-1865$ & 15 & 12 & 1.25 \\
\hline
\end{tabular}

${ }^{1}$ Dates between first and last fire scar. Includes all material.

As progressively shorter periods are selected for computing fire frequency, the interval becomes even shorter. For period 6, a 15-year period (1850-1865), fires were occurring on the Chimney Spring area at 1- to 2-year intervals (average 1.25 years).

Fire-scar data from specimens 2 and 3, only 20 feet $(6 \mathrm{~m})$ apart, show why a single tree does not necessarily reveal the true fire interval for a particular area. Whereas tree 2 had an average interval of 7.6 years for 18 fires, and tree 3 had an interval of 5.9 years for 16 fires, the CFI is 5.3 years based on 11 fires that were common to both trees and 12 fires that affected one specimen and not the other.

\section{Discussion}

Two factors appear to be primarily responsible for the extremely short CFl's found on the Chimney Spring study site: (1) the presence of reliable ignition sources (lightning and man), and (2) the accumulation of sufficient ground fuel to permit the fires to spread once the ignitions occur.

Lightning has been a consistent cause of fires in southwestern forests for centuries. During recent times Barrows ${ }^{4}$ reports that, in the states of Arizona and New Mexico, lightning has caused an average of 1,653 fires per year, with a fire density per unit area of 86 fires per million acres protected. The Coconino National Forest, where the study was done, experiences 327 fires per year and a fire density of 162 fires per million acres protected-the highest of the national forests in this region. In addition, the Southwest is recognized as having some of the most critical fire weather of any region in the country (Schroeder et al. 1964).

Cooper (1960) reviewed a number of historical accounts by early explorers documenting the fact that fire was used by various Southwest Indian tribes for a variety of purposes. Indians hunting and living in the San Francisco Peaks region undoubtedly contributed to fire frequency experienced in the study area.

${ }^{4}$ Barrows, Jack S. 1978. Lightning fires in southwestern forests. Final report prepared by Colorado State University for Intermountain Forest and Range Experiment Station, under cooperative agreement 16-568-CA with Rocky Mountain Forest and Range Experiment Station, Fort Collins, Colo. 154 p. 
Faulk (1970) provides some insight into the possible influence of early settlement in northern Arizona on fire risk. The Homestead Act of 1862 and Timber Culture Act of 1873, along with construction of the Santa Fe Railroad through northern Arizona during the period 1880-1883, undoubtedly increased the chances for human-caused fires. On the other hand, this same settlement may have contributed to a reduction in fire incidence in the area because in 1883 the Aztec Land and Cattle Company was reported to be grazing 60,000 head of livestock in northern Arizona. Grazing by other livestock companies was also underway (Faulk 1970). Heavy grazing over large areas could have the effect of reducing wildfire incidence by utilizing grass cover that had, for years, been the primary medium through which fires spread. This theory provides a possible explanation of why the last recorded fire in the Chimney Spring area occurred about this time.

Speculating on the ecosystem that was present in the Chimney Spring area at the time of the last recorded fire (1876), and drawing from descriptions by early explorers (Cooper 1960), it is apparent that most of the stands were open and park-like. Grass and needles were the primary fire-carrying medium, and fire intensities, even on high firedanger days, would have been relatively low. Sparse ground fuels would account for the fact that fires could move through an area without causing appreciable damage to the residual trees. Many of the trees that had previously sustained fire scars would have been skipped by the fire because of the discontinuity in the light surface fuels.

Condition of the forest floor in an area where fires were burning at 2- to 4-year intervals would be in marked contrast to what is found today. Ample exposure of mineral soil and an increase in available nutrients would have encouraged establishment of natural pine regeneration as well as production of biomass from native grasses and forbs. Ashes and charcoal would have been well incorporated in the mineral soil. Seedling mortality would have been high because of competition for moisture, frost heaving, and successive surface fires.

A precarious balance probably existed between mortality and survival of growing stock needed to perpetuate the ponderosa pine type in this area. However, the uneven-age character of the pine stands existing today is testimony to the fact that survival materially exceeded mortality as the stands began to come under management and protection in the early 1900's.

In contrast to the stand conditions that existed under the influence of a natural fire regime, the current stand conditions reflect long-established land management policies designed to protect the areas from wildfire. This protection, in the absence of extensive prescribed burning programs, has resulted in (1) an increase in growing stock to the extent that many areas are now heavily overstocked (Schubert 1974); (2) a significant buildup of natural and activity fuels (Sackett ${ }^{5}$ ); and (3) an apparent reduction in the distribution and density of native grasses because of increased shading and accumulation of pine litter.

${ }^{5}$ Sackett, Stephen S. Reducing natural ponderosa pine fuels using prescribed fire: Two case studies. Manuscript in progress. Rocky Mountain Forest and Range Experiment Station, Fort Collins, Colo.

\section{Literature Cited}

Arno, Stephen F. 1976. The historical role of fire on the Bitterroot National Forest. USDA Forest Service Research Paper INT-187, 29 p. Intermountain Forest and Range Experiment Station, Ogden, Utah.

Arno, Stephen F., and Kathy M. Sneck. 1977. A method for determining fire history in coniferous forests of the mountain West. USDA Forest Service General Technical Report INT-42, 28 p. Intermountain Forest and Range Experiment Station, Ogden, Utah.

Boyce, J. S. 1921. Fire scars and decay. The Timberman 22(6):37.

Cooper, Charles F. 1960. Changes in vegetation, structure, and growth of southwestern pine forests since white settlement. Ecological Monographs 30(2):129-164.

Craighead, F. C. 1927. Abnormalities in annual rings resulting from fires. Journal of Forestry 25:840-842.

Faulk, Odie B. 1970. Arizona: A short history. 266 p. University of Oklahoma Press, Norman, Okla.

Hall, Frederick C. 1976. Fire and vegetation in the Blue Mountains-Implications for land managers. p. 155-170. In Proceedings of the annual tall timbers fire ecology conference, Tallahassee, Fla. [Portland, Oreg., Oct. 1617, 1974] Pacific Northwest 15, 280 p.

Keen, F. P. 1937. Climatic cycles in eastern Oregon as indicated by tree rings. Monthly Weather Review 65:175188.

Keen, F. P. 1940. Longevity of ponderosa pine. Journal of Forestry 38:597-598.

Kotok, E. I. 1933. Fire, a major ecological factor in the pine region of California. p. 4,017-4,021. In Proceedings of the fifth Pacific scientific congress. Volume $\mathrm{V}$ [Division of Biological Science, 1933 Victoria and Vancouver, British Columbia] University of Toronto Press, Toronto, Ontario.

Lemon, Paul C. 1937. Tree history-Six fires 1717-1936. U.S. Department of Agriculture, Forest Service, Rocky Mountain Regular Bulletin 20(6):13. Denver, Colo.

McBride, Joe R., and Richard D. Laven. 1976. Scars as an indicator of fire frequency in the San Bernardino Mountains, California. Journal of Forestry 74(7):439-442.

Munger, Thorton T. 1917. Western yellow pine in Oregon. U.S. Department of Agriculture, Agriculture Bulletin 418, 48 p. Washington, D.C.

Plummer, Fred G. 1912. Forest fires: Their causes, extent, and effects, with a summary of recorded destruction and loss. U.S. Department of Agriculture, Forest Service Bulletin 117, 39 p. Washington, D.C.

Rowdabaugh, Kirk M. 1978. The role of fire in the ponderosa pine-mixed conifer ecosystems. M.S. thesis, Colorado State University, Fort Collins. 121 p.

Schroeder, Mark J., Monte Glovinsky, Virgil F. Hendricks, et al. 1964. Synoptic weather types associated with critical fire weather. USDA Forest Service Unnumbered Publication, 492 p. Pacific Southwest Forest and Range Experiment Station, Berkeley [in cooperation with Weather Bureau, U.S. Department of Commerce, Representative for Office of Civil Defense, Office of the Secretary of the Army] [National Technical Information Service, Accession AD-449-630, Springfield, Va.] 
Schubert, Gilbert H. 1974. Silviculture of southwestern ponderosa pine: The status of our knowledge. USDA Forest Service Research Paper RM-123, 71 p. Rocky Mountain Forest and Range Experiment Station, Fort Collins, Colo.

Soeriaatmadja, R. E. 1966. Fire history of the ponderosa pine forests of the Warm Springs Indian Reservation, Oregon. Ph.D. dissertation. Oregon State University. Dissertation Abstract International Order 27:2612-B. University Microfilms International, Ann Arbor, Mich.

Show, S. B., and Kotok, E. I. 1924. The role of fire in the California pine forests. U.S. Department of Agriculture, Agriculture Bulletin 1294, 80 p. Washington, D.C.

Weaver, Harold. 1943. Fire as an ecological and silvicultural factor in the ponderosa pine region of the Pacific slope. Journal of Forestry 41:7-15.
Weaver, Harold. 1951. Fire as an ecological factor in the southwestern ponderosa pine forests. Journal of Forestry 49:93-98.

Weaver, Harold. 1955. Fire as an enemy, friend, and tool in forest management. Journal of Forestry 53:499-504.

Weaver, Harold. 1959. Ecological changes in the ponderosa pine forest of the Warm Springs Indian Reservation in Oregon. Journal of Forestry 57:15-20.

Weaver, Harold. 1961. Ecological changes in the ponderosa pine forest of Cedar Valley in southern Washington. Ecology 42(2):416-420.

Weaver, Harold. 1974. Effects of fire on temperate forests: Western United States. p. 279-319. In Fire and ecosystems. T.T. Kozlowski and C.E. Ahlgren, editors. Academic Press, Inc., New York, N.Y.

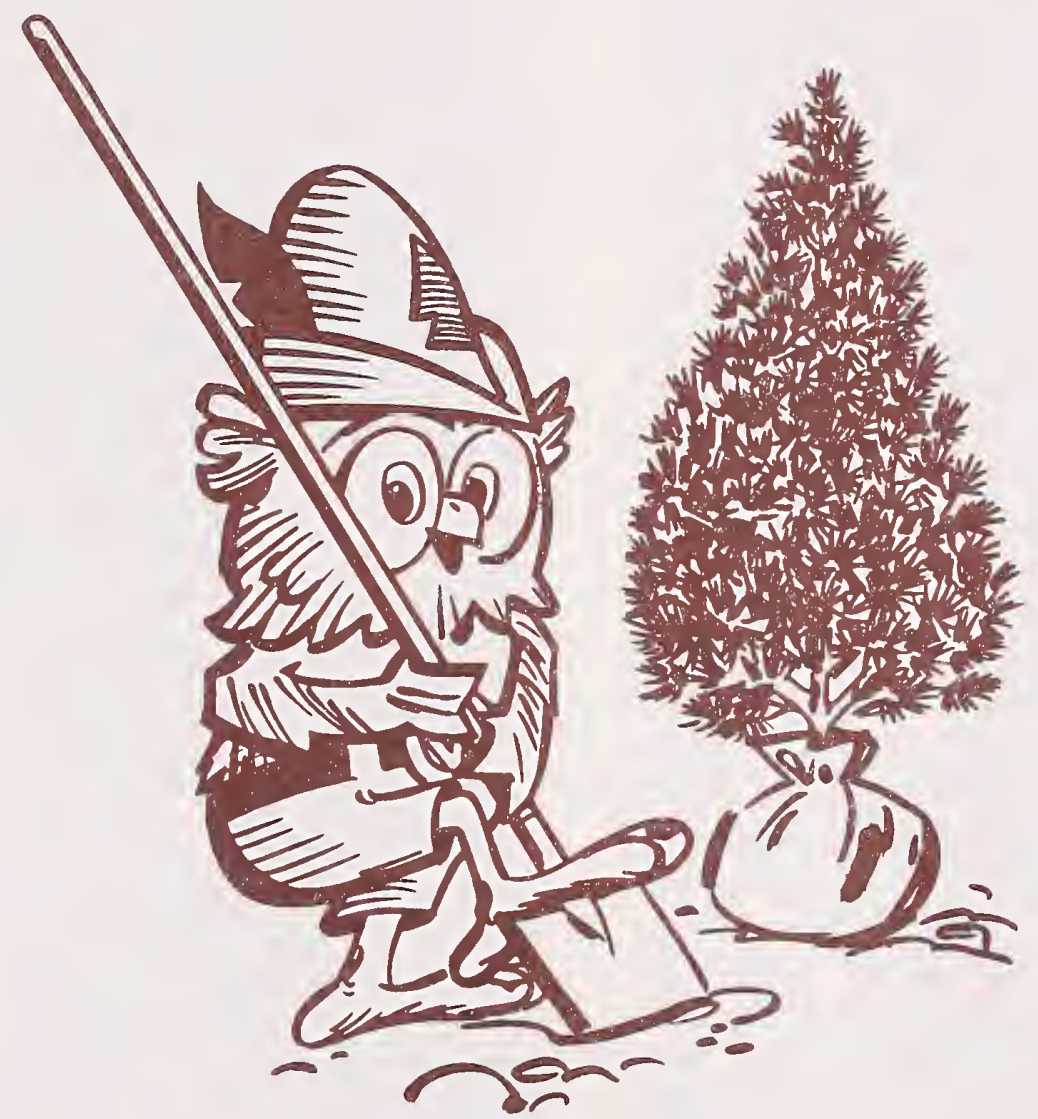

Plant a tree! Mark the 75 th birthday of the Forest Service by giving a living gift to future generations. 

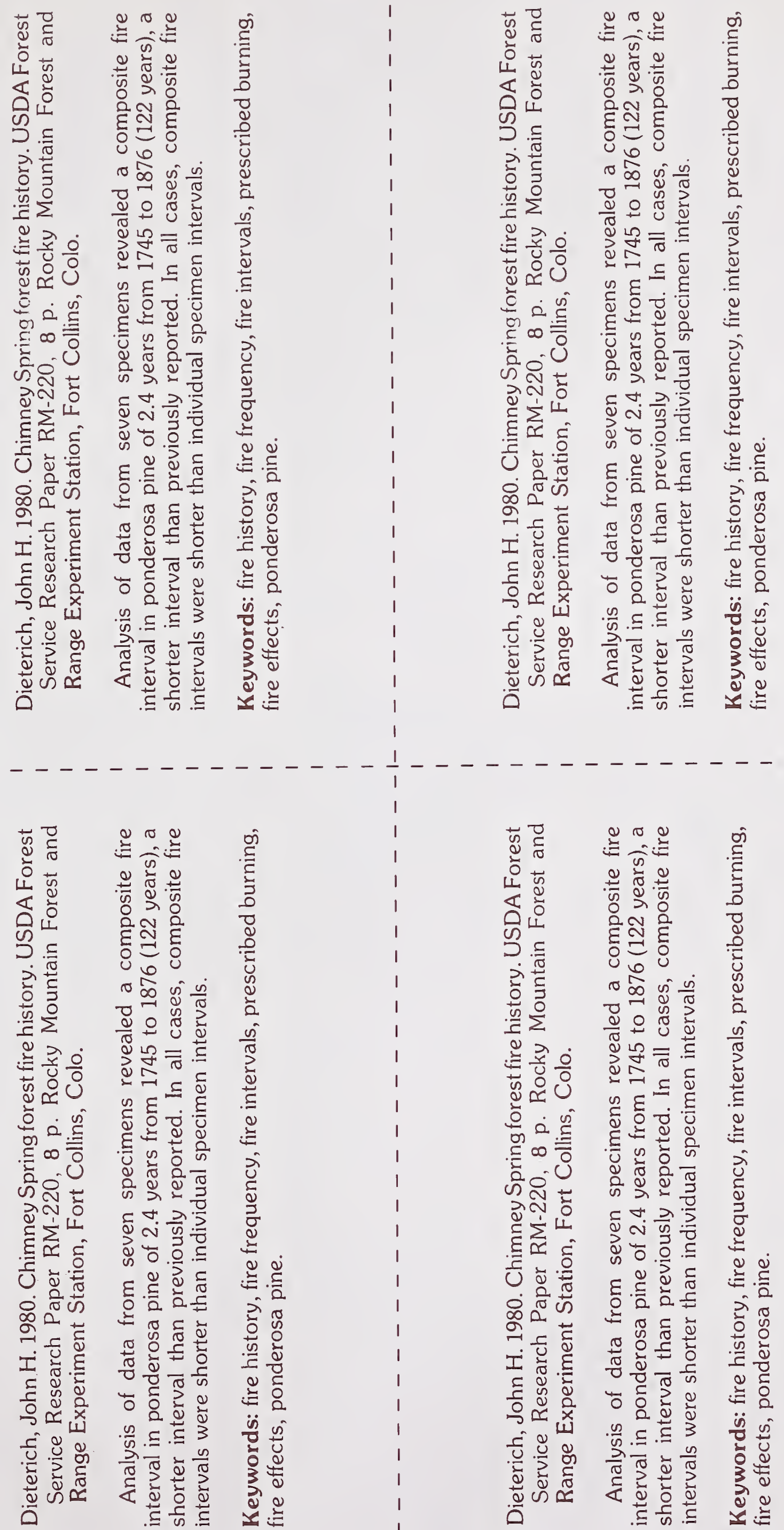


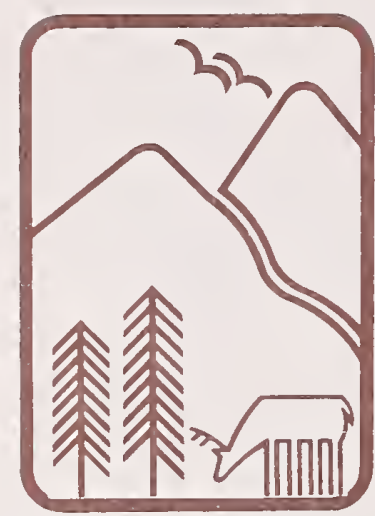

Rocky
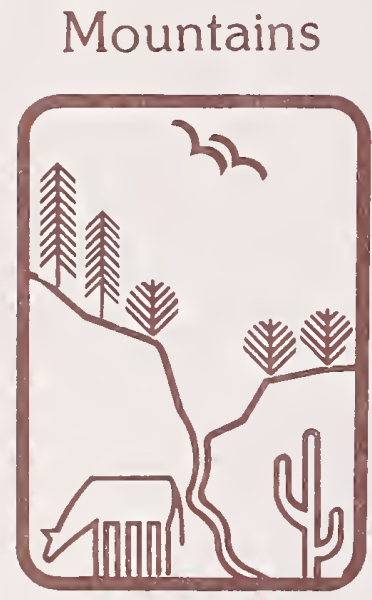

Southwest

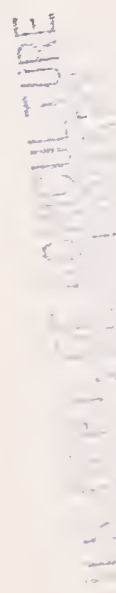

U.S. Department of Agriculture Forest Service

\section{Rocky Mountain Forest and Range Experiment Station'}

The Rocky Mountain Station is one of eight regional experiment stations, plus the Forest Products Laboratory and the Washington Office Staff, that make up the Forest Service research organization.

\section{RESEARCH FOCUS}

Research programs at the Rocky Mountain Station are coordinated with area universities and with other institutions. Many studies are conducted on a cooperative basis to accelerate solutions to problems involving range, water, wildlife and fish habitat, human and community development, timber, recreation, protection, and multiresource evaluation.

\section{RESEARCH LOCATIONS}

Research Work Units of the Rocky Mountain Station are operated in cooperation with universities in the following cities:

Albuquerque, New Mexico

Bottineau, North Dakota

Flagstaff, Arizona

Fort Collins, Colorado*

Laramie, Wyoming

Lincoln, Nebraska

Lubbock, Texas

Rapid City, South Dakota

Tempe, Arizona

"Station Headquarters: 240 W. Prospect St., Fort Collins, CO 80526 